$\xi^{2}=1$ 줄

\title{
Alkaline rocks of the northern part of Birnin Gwari schist belts, northwestern Nigeria: provenance and evolution
}

\author{
Kehinde O. Oluyede \\ Department of Geology, Ahmadu Bello University Zaria, Nigeria \\ (e-mail: olulekeoluyede@gmail.com)
}

\begin{abstract}
Rocks of the northern part of Birnin Gwari schist belt is underlain predominantly by (i) banded gneiss of dioritic and granodioritic composition and granitic gneisses; (ii) biotite-staurolite quartz schist; and (iii) syn-tectonic biotite hornblende (quartzolite - BHG) granite, biotite granite (BG), and biotite-muscovite granite (BMG). Banded gneiss rocks are of hybrid sedimentary-igneous protoliths; their pelitic and mafic protoliths were derived essentially from a quartz-diorite, granodiorite and granite-quartz monzonite source. Metasediments are enriched in $\mathrm{SiO}_{2}$ (63.03 to 65.13 wt \%), with moderately elevated $\mathrm{Al}_{2} \mathrm{O}_{3}(15.4-15.16$ wt \%) values and depleted in $\mathrm{Ba}, \mathrm{V}, \mathrm{W}, \mathrm{La}, \mathrm{Nb}, \mathrm{Nd}, \mathrm{Rb}$, Th and $\mathrm{Zr}$ trace elements; inherited from shale-greywacke sedimentary protoliths. Cogenetic syn-tectonic granites display similar trace elements and REE patterns, with diverse trends such as "normal", "anomalous" and "strongly differentiated" and characterized by LILE enrichment, high LREE fractionation factor ( $\mathrm{La} / \mathrm{Yb}$ of 6.74 to 45.14 ) with weak to moderate negative Eu $\left(\mathrm{Eu} / \mathrm{Eu}^{*}=0.38\right.$ to 0.62$)$ and strong negative $\mathrm{Nb}, \mathrm{P}$ and Ti anomalies. The belt consists of rocks with alkaline affinity and evolved as back arc behind subducted Pan-African plate due effect of compressional forces and differentiation of quartz diorite, granodioritic and granitequartz monzonite magma and partial melting of crustal components inherited from shale-greywacke sedimentary protoliths in volcanic arc and post collisional settings. The precursor of these rocks originated from basalt of depleted mantle that differentiated progressively to the granite.
\end{abstract}

Keywords: Birnin Gwari; Banded Gneiss; Sedimentary; Protolith; Volcanic Arc; Granite.

\section{Introduction}

Precambrian Basement Rocks of Birnin Gwari schist belt consists of Migmatite-Gneiss-Quartzite suite represented by dioritic, granodioritic, granitic gneisses, biotite-staurolite quartz schist and syn-collisional granite. The Schist belt and the underlying quartzofeldspathic rocks of the Zungeru Formation form a single structural unit named Zungeru-Birnin Gwari Schist Belt. It is a simple N-S syncline, $150 \mathrm{~km}$ long, with the northern part displaced dextrally by a NE-SW Kalangai-Zungeru-Ifewara transcurrent fault. It is characterized by conspicuous NNE-SSW trending ridges rising over $100 \mathrm{~m}$ above surrounding country, comprising mainly phyllites, mica schists, with which metagreywacke, pebbly schist and metavolcanics are interlayered. The lower part (south of the study area) consists of finely banded phyllites to the west and higher grade biotite-muscovite schists to the east.

Earliest work on the Birnin Gwari Schist belt was by Truswell and Cope (1963), Turner (1983), Ajibade (1980) and Ajibade et al. (2008); they reported a gneissic and migmatitic assemblage with intercalated quartzites and amphibolites; the metasedimentary greenschist-facies which consists of metapelites, meta-semipelites and metamorphosed mudstone conglomerates member (the Durumi Pebbly Schist Member) preserved in the synclinal core of the belt. They also reported a suite of granitic rocks ranging from diorite to coarsegrained porphyritic granite (the Older Granites). Grant (1978) described the structures in this belt where he recognised a simple N-S structural style, and $\mathrm{Rb}-\mathrm{Sr}$ whole rock data from the adjacent Zungeru mylonites that have yielded ages varying from $600 \mathrm{Ma}-700 \mathrm{Ma}$. Radiometric age measurement of $\mathrm{Rb}-\mathrm{Sr}$ data from nearby Kusheriki granite emplaced across the gneissic envelope gives an age of 500 + 4 Ma. which suggests Pan-African deformation and emplacement in the region (Ajibade et al., 1979; 2008). They described a complex structural sequence from parts of the neighbouring Birnin-Gwari Schist and Ushama Schist Formations and identified four deformation episodes that have affected the rocks in these areas and later define the Zungeru Mylonites. They also confirmed the presence of two types of migmatites and gneisses which are believed to belong to two different ages. Garba (2002) also revealed epigenetic gold-sulphide mineralization hosted by sub-parallel shear zones along isoclinal axes of tightly folded graphitic phyllites near Tsohon Birnin Gwari similar to Bin Yauri area (Zuru schist belt) and other areas of Archaean and younger mesothermal gold mineralization in the world. The belt is considered to be Upper Proterozoic supracrustal rocks which have been infolded into a migmatite gneiss quartzite complex. The NE-SW Kalangai-Zungeru-Ifewara (KZI) transcurrent fault dextrally displaced this belt in the south (Fig. 1). The Birnin Gwari schist belt occurs close to the Kushaka counterpart, and is separated by the migmatite-gneiss-quartzite rock suite. Although ages of rock in the two belts ranges from Archaean to Pan-African; rocks of Birnin Gwari schist belt have been assigned Pan-African age. 
The northern part of Birnin Gwari which is the focus of this study consists predominantly of banded gneiss of dioritic, granodioritic compositions and granitic gneisses; staurolite-biotite quartz schists with lithic (angular to rounded clastic quartz, schistose, volcanic and quartzo-feldspathic) materials and syn- tectonic granite (Fig 1). Although, the Birnin Gwari schist have benefited from research in structural and geochemical controls of mineralization and interest by mineral prospectors as well as economic geologists; relatively little information has emerged concerning geochemistry of different rock types that constitute the basement. In this work, major, trace and rare earth elements (REE) data on nineteen different rocks types have been used to assess their provenance and tectonic setting. This is to gain understanding of the evolution of the major rock units of the Precambrian basement of Nigeria.

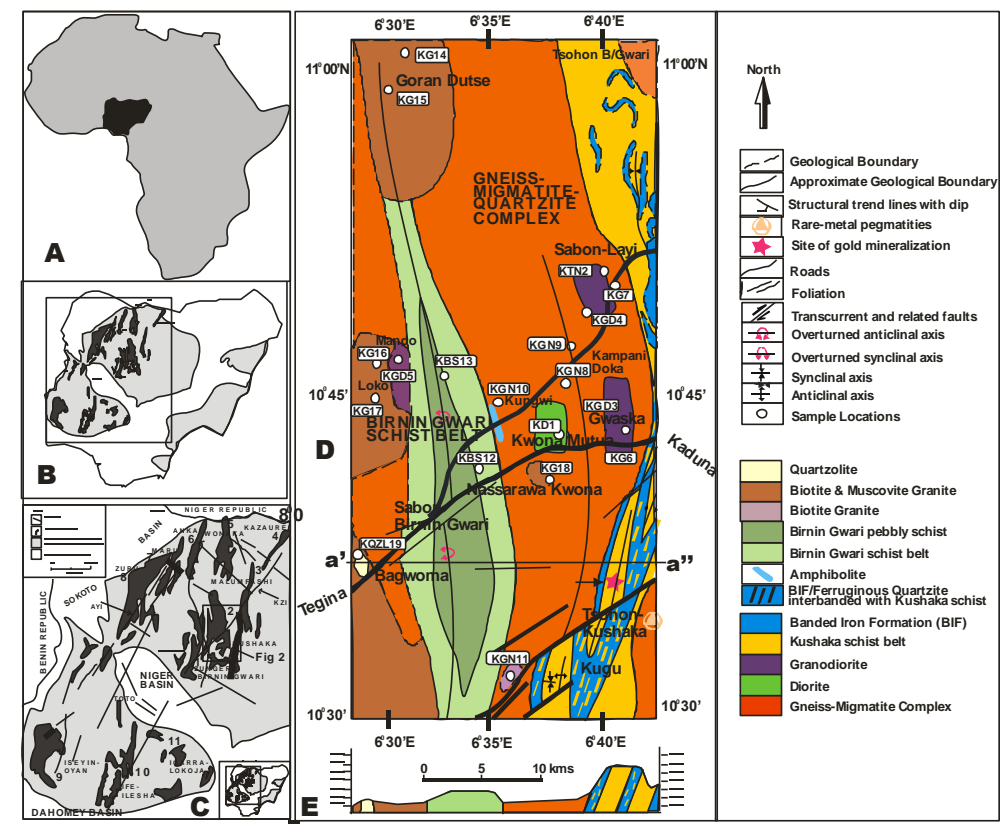

Fig. 1: Geological Map of Northern Part of Birnin Gwari Schist Belt (Sheet 122) Modified After Truswell and Cope, (1963).

\section{Methodology}

Nineteen representative (11 gneiss; 6 granite, and 2 schist) samples were selected and thin sections were prepared and petrographic studies of different rock types were done using a petrographic research microscope at the Department of Geology, Ahmadu Bello University, Zaria. Modal compositions of the rocks were estimated from thin section studies using the JMicrovision software of Nicholas Roduit version 1.2.7. (2002-2008). About $1 \mathrm{~kg}$ of each sample was broken into pieces with a hammer and crushed into smaller pieces with a jaw-crusher in preparation for analysis. The samples were thereafter pulverized in a disc mill for about two minutes. Each pulverised sample was thoroughly homogenized to obtain a representative portion. The samples were thereafter sent to laboratories for whole-rock geochemistry in the Department of Lithospheric Research, University of Vienna, Austria, while REE analyses were done in MSALABS Langley, Canada. Rocks were crushed and ground to the finest powder possible in an agate (or tungsten carbide) swing mill for the whole X-ray-fluorescence analysis. Major elements were determined by fused bead method on calcined rock powder fused with lithium tetraborate as flux to form a glass bead. Trace elements used the pressed pellet method directly on the crushed and milled rock powder mixed with polyvinyl alcohol as a binding agent. The element analyses in a sequential mode on X-Ray spectrometer PHILIPS PW2404 using a super-sharp end-window tube with a Rh-anode and a programmable 4kW generator $(60 \mathrm{kV}$ max., $125 \mathrm{~mA}$ max.; isoWatt-switching), with accompanying PANalytical software. REE analyses were done using a lithum metaborate/tetraborate flux in a platinum crucible and fused samples poured into a platinum mould to create a homogenous glass disk and then analysed by X-rayflourescence (XRF).

\section{Results and discussion}

\subsection{Lithology and field relations}

The basement sensu stricto comprises of banded gneiss, granite and granitic gneisses; the metasedimentary schist belt is represented by biotite-staurolite quartz schist; while syn-collision granite is represented by biotite granite (BG) and biotite-muscovite granite (BMG). Detail petrographic description is contained in the work of Oluyede et al. (2020).

\subsubsection{Banded gneiss}

Banded gneiss consists of migmatites as well as palaeosome and leucosome of dioritic, tonalitic, granodioritic and granitic composition. The migmatites occur as foliated high and low level outcrops, with plastic deformation, meso and microscopic fold structure and well preserved $\mathrm{N}-\mathrm{S}$ schistocity, with alternating dark bands of biotite and other dark minerals $(2-6 \mathrm{~cm})$ and light quartzo-fedspathic minerals. They are also characterized by symetrical and asymetrical boudinage, eye ball structure and decimeter sized isoclinals $F_{2}$ folds with $S_{1}$ parallel to the axial plane schistocity and in places with crestal thickening (Fig. 2). The S-type paleosome occurs with predominant pyroxene minerals and I-type leucosome as injections with dextral sense of displacement. Petrographic work has revealed essential minerals as quartz, K-feldspars (orthoclase, microcline), plagioclase, pyroxene, hornblende, biotite, muscovite and the accessory minerals are sphene, zircon, iron oxide (magnetite and hematite). Abundant pyroxene minerals in the banded gneiss lend credence to 
anatexis; where amphibolite facies metamorphism may have locally attained grannulite facies (Fig. 3A). Detailed geological, structural mapping and geochemistry of the banded gneiss of the study area is seen in the work of (Oluyede et al. (2021a and b).

\subsubsection{Tonalites}

Tonalites are exposed along River Rafin Magami and occur as boulders and whale backs which are traceable westward for a few kilometers from the bridge across the Birnin Gwari - Funtua road, north of Sabo-Layi village. It is a fine to medium grained rock, grey in colour and weakly foliated. Microscopically, it consists of plagioclase (55\%), quartz (20\%), Biotite (10\%), orthoclase (10\%), pyroxene (5\%) with accessory iron-oxide (haematite and magnetite) and apatite.

\subsubsection{Granite gneiss}

Granite gneisses are weakly foliated fine to medium grained grayish and reddish brown equi-grannular rocks with biotite, muscovite quartz and feldspar minerals. They are easily distinguished from the migmatites because they are not strongly foliated, devoid of admixture of varied phases and do not preserve the original tight isoclinals folds. They differ from banded gneiss because they do not have thick bands of paleosome and leucosome injections. They are represented by biotite, staurolite and muscovite, which are products of metasomatism (Fig. 3B).

\subsubsection{Schist}

The Birnin Gwari schist occurs as an elongate, N-S trending metasedimentary outcrop of $430 \mathrm{~m}$ elevation, and as a whale back outcrop exposed along Kogi Kusheriki river channels, through Mando. It consists of light and dark coloured staurolite and biotite quartz schists with clastic quartz, schistose, volcanic and quartzo-feldspathic materials (Fig. 2C). The angular, rounded and flattened poorly sorted clast ( $2 \mathrm{~mm}$ to $5 \mathrm{~cm}$ and making up to $25-40 \%$ of the constituent of the rock) is aligned in the foliation direction. The dark coloured types close to the Mando granitic intrusion are fine grained with granular texture without clastic materials. Microscopically, they consist of staurolite (30\%), quartz (30\%), K-feldspar (20\%), muscovite (10\%) and iron-oxide (5\%). Biotite crystal is sub-hedral to anhedral and sometimes aligned with quartz and staurolite minerals (Table 1) (Fig. 3C).

\subsubsection{Amphibolite}

The amphbolite outcrop is located at Kungwi area (N10 $43^{\prime} 17^{\prime \prime}$ E $\left.6^{0} 34^{\prime} 30^{\prime \prime}\right)$. It is medium grained dark, weakly foliated dark green with subhedral quartz crystals. It shows characteristic brittle deformation with fragmented boulders with N-S directional trend (Fig. 1). Microscopically, it consists essentially of subhedral light brown hornblende (50\%) with blue tint, quartz (20\%), plagioclase (15\%), biotite $(5 \%)$ and pyroxene $(5 \%)$. Accessory minerals are iron-oxide (haematite and magnetite) and zircon.

\subsubsection{Syn-collision granite}

The granite plutons intruded both the Migmatite-Gneiss-Quartzite suite and the Birnin Gwari schist in Gworon Dutse, Mando, Loko, Bagwoma, Birnin Gwari and Kugu. These intrusions form N-S excellent oval and elongated bodies and whaleback outcrops on the edges of the Birnin Gwari schists on the western side of transcurrent Kalangai fault (Fig. 1). They occur as porphyritic, coarse porphyritic and medium to fine grained, and are generally devoid of pervasive foliation. The porphyritic type consists of grey colour feldspar and quartz, contrasted by dark colour biotite and shining and flaky muscovite. In hand specimen the dark minerals shows no preferred orientation and form rims around the quartz minerals. Petrographically, the rock shows quartz (35\%), K-feldspar (35\%), muscovite (5\%), biotite $(15 \%)$, plagioclase $(5 \%)$ and iron-oxide $(5 \%)$, with accessory magnetite, illmenite, titanite and apatite (Fig. 3D and E). The medium grained types are found in Mando and Loko area showing sharp contact with the metasediments with chilled margins (Fig. 2D); observable minerals include pinkish to milky feldspars, silvery muscovite flakes, and black to brownish biotite, in places slightly weathered and brownish green muscovite. Under the microscope, quartz $(30 \%)$ occur as subhedral phenocryst together with plagioclase $(5 \%)$, orthoclase $(20 \%)$ and microcline $(20 \%)$, as well as medium grain euhedral crystals, closely interlocked with each other and with biotite $(10 \%)$ and muscovite $(10 \%)$ forming part of the groundmass. Accessory minerals include magnetite and apatite (Fig. 2E). Quartzolite forms an isolated outcrop northwest of Bagwoma dam. It's a light coloured rock with grey, white, milky and reddish brown colours and coarse grain fibroblastic texture; with preferred mineral banding $\left(360^{\circ} \mathrm{NS}\right)$, light brown to reddish brown biotite and hornblende. Petrographically, the rock consists of quartz (60\%), K-feldspar (10\%), hornblende (15\%), and biotite (10\%) strongly aligned. Observable alteration is seritization where K-feldspar is altered to an aggregate of finely divided white mica. Hornblende is anhedral, lathlike and elongated with pale brown \& reddish brown crystals (Fig. 3F).
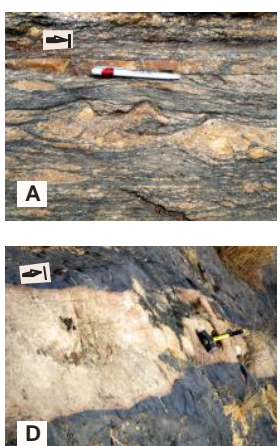
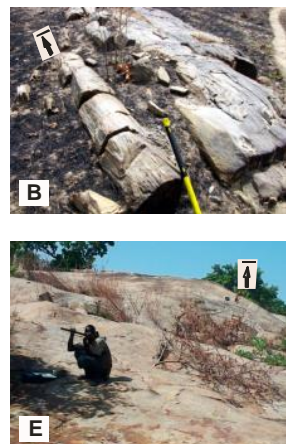
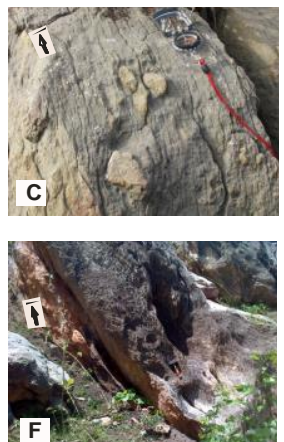

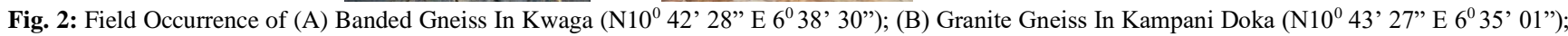
(C) Birnin Gwari Staurolite Schist (N10 41'24" E 6 32' 58"); (D) Granitic Dyke in Staurolite and Biotite Schist in Birnin Gwari/Mando Contact; (E) Birnin Gwari Biotite-Muscovite Granite (N10 43' 27' E 6 33' 74”) and (F) Quartzolite In Bagwoma Area (N10 39' 15” E 6 30' 45”). 

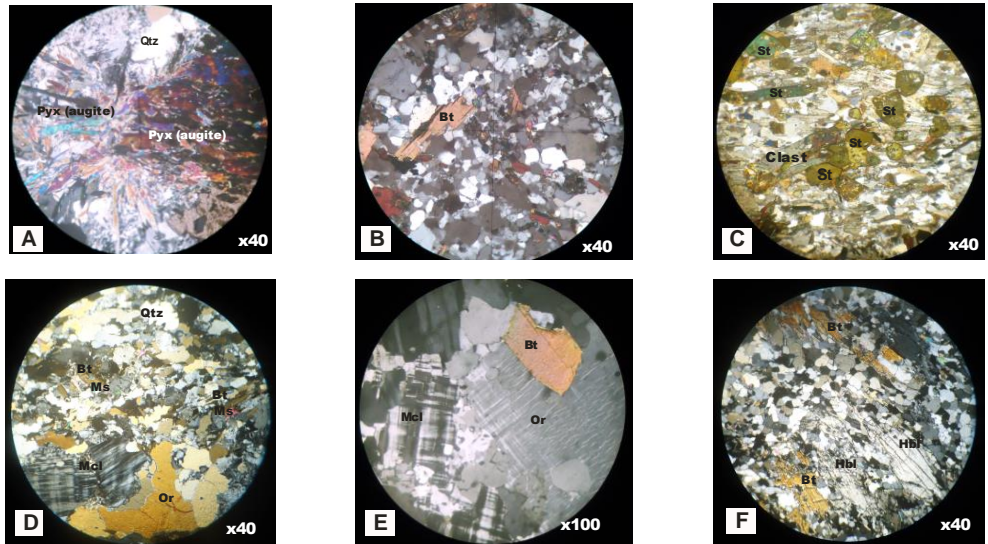

Fig. 3: Photomicrograph of (A) Basalt in Kushaka Gneiss Complex (B): Banded Gneiss Paleosome; (C) Banded Gneiss Leucosome; (D) Tonalite In SaboLayi; (E) Biotite And Staurolite Gneiss In Gwagwaulu and (F) Hornblende Biotite Syenite in the Kushaka Schist Belt. (St=Staurolite, Qtz=Quartz, $\mathrm{Mcl}=$ Microcline, $\mathrm{Bt}=$ Biotite, $\mathrm{Ms}=$ Muscovite, Or-Orthoclase, $\mathrm{Hbl}=\mathrm{Hornblende}$ ).

\subsection{Geochronology, deformation and metamorphism}

The basement rocks underlying Birnin Gwari schist had undergone a polycyclic metamorphism with Eburnean, Kibaran and Pan-African tectonothermal events (Table 1) (Oyinloye, 2011), but the metasediments have been assigned Pan-African (Ajibade et al, 2008). Series of deformation fabrics and evolutionary episodes had been recorded in these rocks. Four deformational episodes as observed in the field $\left(\mathrm{D}_{1}\right.$ $-\mathrm{D}_{4}$ ) have led to the generation of three major foliation trends namely: near vertical N-S, NNE-SSW and NE-SW (Grant, 1978; Oluyede et al., 2021a). The planar (foliation) surfaces were observed mainly in the migmatite-gneiss (-quartzite) complex and the Birnin Gwari metasedimentary rocks while joints and fractures cut across all lithologies in the area. Imprints of Pan-African thermo-tectonic events have shown observable migmatization as the first thermo-tectonic event resulting in plastic deformation $D_{1}$ and regional $S_{1}$ foliation, outlined by tight isoclinals fold, compositional banding and $\mathrm{N}-\mathrm{S}$ preferred orientation of dark minerals. The $\mathrm{D}_{2}$ deformation is co-axial with $\mathrm{D}_{1}$ and resulted in the formation of decimeter sized $\mathrm{F}_{2}$ isoclinal folds, $\mathrm{B}_{2}$ boudins and eye ball structures that are parallel to $\mathrm{S}_{1}$ plane schistosity and in places with eye ball structure, boudinage and crestal thickening (Fig. 2A). The D 3 deformations is not observed in the Birnin Gwari metasediment but present in the Kushaka ferruginous quartzites and observed as fragmentation in the proto-mylonitic staurolite schist in the Kushaka Gneiss Complex; here also the $F_{3}$ open fold refolded or transposed the earlier tight isoclinal $F_{2}$ folds. The $\mathrm{D}_{4}$ deformation resulted in N-S and NW-SE quartz veins and pegmatite dykes which serve as channels for epigenetic gold-sulphide and rare metal bearing ore fluids. Abundant pyroxene minerals especially in banded gneiss of dioritic and granodioritic compositions (Fig. 3A) have shown that amphibolite facies metamorphism may have locally attained grannulite facies.

Table 1: A Modified Sequence of Events in the Basement Rocks of the Birnin Gwari Schist Belt NW Nigeria (Modified from Oyinloye, 2011)

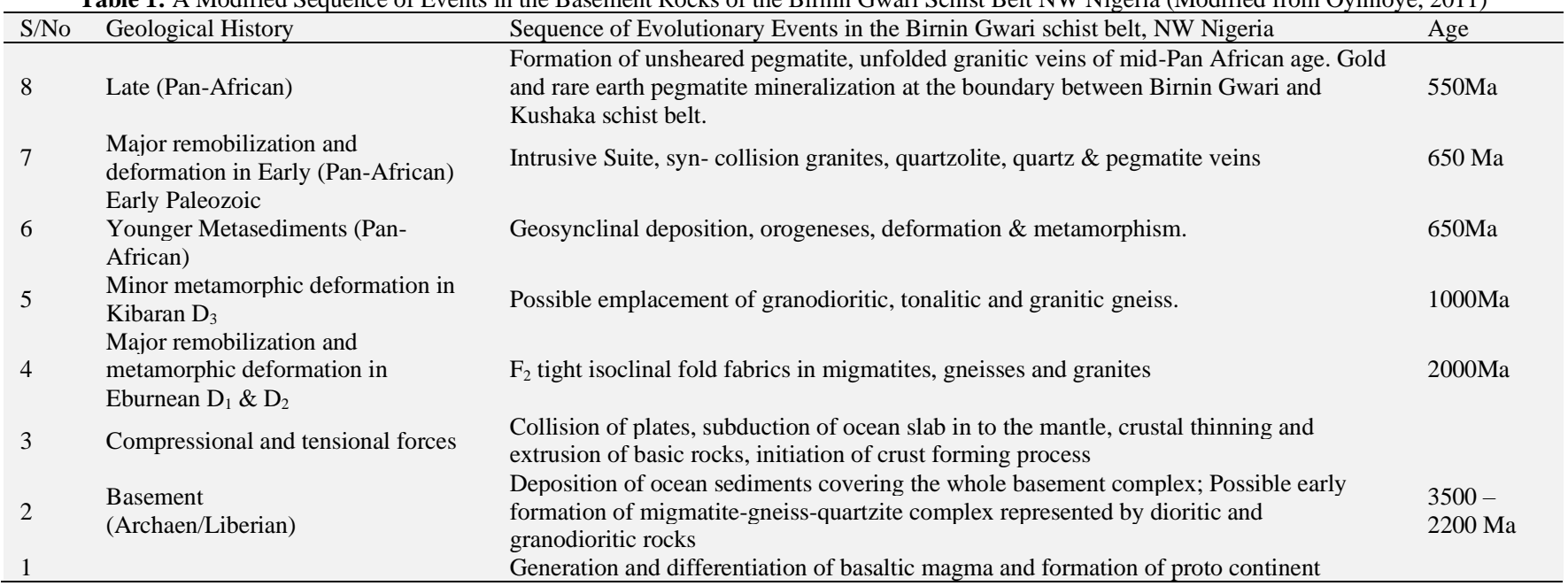

\subsection{Geochemistry and petrogenesis}

Using geochemical indices, discrimination diagrams and chemical affinities, the rocks revealed the followings:

1) The rock samples display a marked variation in the abundance of silica content from 60.77 to $67.11 \mathrm{wt} \%$ in banded gneiss (diorite, granodiorite) and tonalite; 70.49 to $77.63 \mathrm{wt} \%$ in granite gneiss; 73.61 to $76.73 \mathrm{wt} \%$ in granite and leuco-granite; $63.03-65.13$ wt $\%$ in staurolite-biotite-muscovite quartz mica schist and $82.42 \mathrm{wt} \%$ in quartzolite (Table 2), which shows rocks of intermediate and acidic composition suggesting diverse protolith.

2) Moderate to high $\mathrm{Al}_{2} \mathrm{O}_{3}$ content $(12.65-15.99 \mathrm{wt} \%)$ in all rock types reflect high feldspars content and the pelitic nature of the banded and granitic gneiss and staurolite-biotite-muscovite quartz-mica schist.

3) There is high $\mathrm{Fe}_{2} \mathrm{O}_{3}, \mathrm{CaO}, \mathrm{MgO}$ content in diorite, tonalite, granodiorite and schist; moderate $\mathrm{Fe}_{2} \mathrm{O}_{3}, \mathrm{CaO}, \mathrm{MgO}$ content in granitic gneiss and low $\mathrm{Fe}_{2} \mathrm{O}_{3}, \mathrm{CaO}, \mathrm{MgO}$ content in granite and leuco-granite. Enrichment in the mafic oxides reflects high contents of mafic minerals (biotite, hornblende and pyroxenes).

4) The $\mathrm{Na}_{2} \mathrm{O}$ and $\mathrm{K}_{2} \mathrm{O}$ content is moderate to high in diorite, granodiorite and tonalite, granitic gneiss, granites and staurolite-biotitemuscovite quartz mica schist but low in quartzolite. $\mathrm{K}_{2} \mathrm{O}$ content is generally higher than $\mathrm{Na}_{2} \mathrm{O}$ content. Additionally, the ratio of 
$\mathrm{K}_{2} \mathrm{O} / \mathrm{Na}_{2} \mathrm{O}$ is diverse in the rock types but show moderate to high in diorite (2.50), some banded and granitic gneiss (BD1, BGD4, BG6, BGN10) samples $(1.09-2.77)$ and staurolite-biotite-muscovite quartz schist (1.03-1.15) and some granite and quartzolite samples $(0.82-1.46)$, this reflect high amount of K-feldspar and plagioclase; igneous nature of the granites, hybrid nature (metasedimentary and igneous protolith) of banded and granitic gneiss, and metasedimentary nature of the staurolite-biotite-muscovite quartz mica schist and quartzite.

All rock types of the Birnin Gwari schist belt show alkaline affinity, except for the samples (BG7, BGN11 and BQZL19) as observed from the discrimination plot of Irvine and Baragar (1971) (Fig. 4A). On the discrimination diagram of Garrels and Mackenzie (1971) (Fig. 4B), diorite, granite gneiss sample (BGN11), quartzolite (BQZL19) and biotite-staurolite-muscovite quartz schist plot within the sedimentary/metasedimentary field, showing that they are of sedimentary origin; one banded (BGD4) and leucogranite (BG6) samples plot in the boundary between sedimentary/metasedimentary and igneous field which imply that the magma which gave rise to the precursor rocks of these gneisses originated from a mixed source containing igneous and sedimentary materials. The tonalite, granite and granite gneiss samples plot in the igneous field, and are of magmatic origin. The ASI vs. A/NK $=\mathrm{Al}_{2} \mathrm{O}_{3} /\left(\mathrm{Na}_{2} \mathrm{O}+\mathrm{K}_{2} \mathrm{O}\right.$ mol \%) of Frost et al. (2001) discriminating diagram has shown that the rock units are mainly peraluminous in nature except for diorite, tonalite and a granodiorite sample that is metaluminous (Fig. $5 \mathrm{~A}$ ). The observed peraluminous character (ASI $\geq 1$ ) reflects the presence of Na-rich minerals with the samples yielding between 1.0 and 1.8. Their peraluminous nature coupled with marked variation in the abundance of silica content reveals that the rocks of Birnin Gwari schist belt were derived mainly from crustal sources with slight contribution from mantle materials. On the $\mathrm{K}_{2} \mathrm{O}$ versus $\mathrm{SiO}_{2}$ plot (after Rickwood, 1989), the diorite, granodiorite and tonalite, granite gneiss and granites plot dominantly in the high-K calc-alkaline and shoshonitic field while the quartzolite plot in the tholeiite field (Fig. 5B). The ACF diagram of Miyashiro (1978) (Fig. 6A) revealed diorite, a granodiorite, tonalite granitic gneiss, granite and quartzolite plot in the shale and greywacke field, suggesting that they originated from shale-greywacke protolith. When plotted on the $\mathrm{CaO}-\mathrm{Na}_{2} \mathrm{O}-\mathrm{K}_{2} \mathrm{O}$ diagram of Condie (1967) (Fig. 6B), and the fields showing the compositional variations in which acid to basic rocks are superimposed, diorite and granodiorite, granitic gneiss, tonalite and staurolite-biotite-muscovite quartz mica schist plot in Granodiorite field, while granite and quartzolite plot in Granite-Quartz-monzonite field. This confirms that Birnin Gwari metasediments are of shale-greywacke protoliths derived essentially from a granodiorite and granitic-quartz-monzonitic source (Oluyede et al. 2021c).

Table 2: A) Major (Wt \%) Abundance in the Basement Rocks of the Northern Part of Birnin Gwari Schist Belt

\begin{tabular}{|c|c|c|c|c|c|c|c|c|c|c|}
\hline Sample & BD1 & BTN2 & BGD3 & BGD4 & BGD5 & BG6 & BG7 & BGN8 & BGN9 & BGN10 \\
\hline$(\%)$ & Diorite & Tonalite & \multicolumn{3}{|c|}{ Granodiorite Paleosome } & \multicolumn{2}{|c|}{ Granite Leucosome } & \multicolumn{2}{|c|}{ Granite Gneiss } & \\
\hline $\mathrm{SiO} 2$ & 60.77 & 64.45 & 63 & 67.11 & 65.24 & 75.44 & 73.61 & 70.49 & 74.42 & 70.74 \\
\hline $\mathrm{TiO} 2$ & 0.93 & 0.6 & 0.84 & 1.3 & 0.82 & 0.11 & 0.62 & 0.45 & 0.26 & 0.6 \\
\hline $\mathrm{Al} 2 \mathrm{O} 3$ & 13.5 & 15.55 & 15.34 & 12.87 & 15.99 & 12.99 & 12.9 & 14.21 & 13.2 & 13.68 \\
\hline $\mathrm{Fe} 2 \mathrm{O} 3$ & 7.04 & 4.78 & 5.67 & 7.69 & 5.13 & 1.32 & 4.08 & 2.55 & 1.55 & 3.91 \\
\hline $\mathrm{MnO}$ & 0.12 & 0.11 & 0.11 & 0.17 & 0.07 & 0.03 & 0.08 & 0.09 & 0.05 & 0.04 \\
\hline $\mathrm{MgO}$ & 4.2 & 2.07 & 2.53 & 1.71 & 2.31 & 0.16 & 0.9 & 0.79 & 0.31 & 1.1 \\
\hline $\mathrm{CaO}$ & 5.2 & 3.71 & 4.93 & 2.62 & 3.06 & 0.82 & 2.48 & 2.31 & 1.24 & 1.15 \\
\hline $\mathrm{K} 2 \mathrm{O}$ & 4.18 & 3.09 & 2.97 & 2.66 & 1.6 & 6.13 & 2.79 & 3.6 & 4.42 & 5.81 \\
\hline $\mathrm{P} 2 \mathrm{O} 5$ & 0.43 & 0.25 & 0.34 & 0.21 & 0.35 & 0.06 & 0.13 & 0.11 & 0.04 & 0.14 \\
\hline LOI & 0.66 & 0.39 & 0.92 & 0.48 & 1.09 & 0.27 & 0.39 & 0.59 & 1.01 & 0.56 \\
\hline Total & 98.7 & 99.12 & 99.68 & 99.24 & 99.53 & 99.87 & 101.19 & 99.11 & 100.21 & 99.82 \\
\hline $\mathrm{K}_{2} \mathrm{O} / \mathrm{Na}_{2} \mathrm{O}$ & 2.50 & 0.75 & 0.98 & 1.09 & 0.41 & 2.41 & 0.86 & 0.91 & 1.19 & 2.77 \\
\hline
\end{tabular}

Table 2: B) Major (Wt \%) Abundance in the Basement Rocks of the Northern Part of Birnin Gwari Schist Belt

\begin{tabular}{|c|c|c|c|c|c|c|c|c|c|}
\hline $\begin{array}{l}\text { Sample } \\
(\%)\end{array}$ & $\begin{array}{l}\text { BGN11 } \\
\text { Granite Gneiss }\end{array}$ & $\begin{array}{l}\text { BSc12 } \\
\text { Schist }\end{array}$ & $\mathrm{BSc} 13$ & $\begin{array}{l}\text { BG14 } \\
\text { Granite }\end{array}$ & BG15 & BG16 & BG17 & BG18 & $\begin{array}{l}\text { BQZL19 } \\
\text { Quartzolite }\end{array}$ \\
\hline $\mathrm{SiO} 2$ & 77.53 & 65.13 & 63.03 & 70.15 & 76.73 & 73.76 & 74.06 & 75.5 & 82.42 \\
\hline $\mathrm{TiO} 2$ & 0.39 & 0.92 & 0.97 & 0.41 & 0.07 & 0.04 & 0.02 & 0.15 & 0.29 \\
\hline $\mathrm{Fe} 2 \mathrm{O} 3$ & 1.93 & 6.62 & 7.3 & 2.41 & 0.64 & 0.66 & 0.36 & 0.99 & 0.03 \\
\hline $\mathrm{MnO}$ & 0.03 & 0.11 & 0.12 & 0.04 & 0.01 & 0.03 & 0.06 & 0.08 & 0.17 \\
\hline $\mathrm{MgO}$ & 0.52 & 2.17 & 3.31 & 0.86 & 0.1 & 0.11 & 0.06 & 0.13 & 1.7 \\
\hline $\mathrm{CaO}$ & 1.5 & 1.93 & 1.69 & 1.94 & 0.87 & 0.41 & 0.45 & 0.45 & 0.04 \\
\hline $\mathrm{Na} 2 \mathrm{O}$ & 2.63 & 2.6 & 2.29 & 3.72 & 4.02 & 4.2 & 4.7 & 4.29 & 0.28 \\
\hline $\mathrm{K} 2 \mathrm{O}$ & 1.93 & 3.01 & 2.36 & 4.86 & 4.52 & 3.87 & 3.89 & 4.14 & 0.41 \\
\hline $\mathrm{P} 2 \mathrm{O} 5$ & 0.08 & 0.19 & 0.62 & 0.12 & 0.03 & 0.42 & 0.51 & 0.02 & 0.02 \\
\hline LOI & 1.04 & 1.25 & 1.03 & 0.35 & 0.42 & 0.97 & 0.7 & 0.51 & 0.57 \\
\hline Total & 100.23 & 99.33 & 97.88 & 99.98 & 101.57 & 99.77 & 99.76 & 99.12 & 100.5 \\
\hline $\mathrm{K}_{2} \mathrm{O} / \mathrm{Na}_{2} \mathrm{O}$ & 0.73 & 1.15 & 1.03 & 1.3 & 1.12 & 0.92 & 0.82 & 0.96 & 1.46 \\
\hline
\end{tabular}

The $\mathrm{TiO}_{2}-\mathrm{K}_{2} \mathrm{O}-\mathrm{P}_{2} \mathrm{O}_{5}$ plot of Pearce et al. (1975) (Fig. 7A) of the diorite, granodiorite and tonalite and granitic gneisses, granite and granite leucosome, quartzolite, as well as biotite-staurolite-muscovite quartz schist all plot in the continental field. The continental field confirms source rock derived from continental crust materials during their genesis. Plots of molar $\mathrm{Al}_{2} \mathrm{O}_{3} /\left(\mathrm{MgO}+\mathrm{Fe}_{2} \mathrm{O}_{3}\right)-\mathrm{CaO} /(\mathrm{MgO}+$ $\mathrm{Fe}_{2} \mathrm{O}_{3}$ ) diagram of Altherr et al. (2000) (Fig. 7B) with composition fields of partial melts derived from experimental dehydratationmelting of various source rocks (Wolf and Wyllie, 1994; Gardien et al., 1995; Partino Douce and Beard, 1995; 1996; Singh and Johanneses, 1996) diorite, granodiorite and tonalite, granitic gneiss, are derived from metabasic to tonalitic sources, granite and some granitic gneisses derived from metagreywacke sources and staurolite-biotite-muscovite quartz mica schist derived from meta-greywacke sources and quartzolite derived from metapelitic sources. On the $\mathrm{Y}+\mathrm{Nb}$ versus Rb discrimination diagram after of Pearce et al. (1984), diorite, granodiorite and tonalite; granitic gneiss, granite and granite leucosome all plotted in the field of post-collision granites and quartzolite plot in the volcanic arc granite (VAG) field (Fig. 8), similar to a back arc tectonic setting. Additionally, Ni composition in diorites, tonalite and one banded gneiss sample (BDG4) varies from 15.3 to $49.3 \mathrm{ppm}$ (Table 3 ) which is lower than that of the rock derived from a primitive upper mantle, implying that their magmatic source may have been metasomatised and fractionally crystallized depleted mantle (Oyinloye, 2011; Machado et al., 2005). This is an indication that mantle materials are from volcanic and back arc environment. Characterization of diorite, granodiorite, tonalite, granitic gneiss, granite, quartzolite and schist from primitive mantlenormalized abundance trace elements patterns (of Sun and McDonough, 1989) (Fig. 9) show similar pattern; this is an implication of 
their close genetic relationship. They show enrichment of the large ion lithophile elements (LILE: Ba, Rb, K) with slight deviation; radioelements $\mathrm{Th}$ and $\mathrm{U}$ and depletion of the high field strength elements (HFSE: $\mathrm{Nb}$ and Ti), an indication of a subduction related environment (Ferre, et al., 1998; Soesoo, 2000; Whalen et al., 1987). There is however progressive decrease in the in the LILE as differentiation progresses from depleted mantle basalt to diorite and granite (Fig. 9B-F).

Chondrite-normalized REE patterns after Boynton (1984) are presented in Table 4 and Fig. 10. diorite, granodiorite, tonalite and granitic gneiss have the sum total of REE $\left(\sum \mathrm{REE}=21.42-382.40\right)$ and granite has $\left(\sum \mathrm{REE}=15.90-201.74\right)$ and the schist has $\left(\sum \mathrm{REE}=\right.$ 139.36). They all have similar distribution pattern of Light Rare Earth Elements (LREE) enrichment relatively to the chondrite than Heavy Rare Earth Elements (HREE), which results in moderate to high degree of fractionation and moderate negative Eu anomaly with $\mathrm{Eu} / \mathrm{Eu}^{*}$ values between $0.37-0.73$. Kugu gneiss (BGN11) and Mando granite (BG16) however exhibit near flat HREE trend [(La/Sm)N $=1.83-2.34]$ with near flat Eu anomaly $\left(\mathrm{Eu} / \mathrm{Eu}^{*}\right.$ values between $\left.0.62-0.66\right)$ and low fractionation $[(\mathrm{La} / \mathrm{Yb}) \mathrm{N}=1.05-6.74]$. These trends show a progressive differentiation of the depleted mantle materials represented by diorite, granodioritic and tonalite to granitic gneisses and granites, which imply that the precursor of these rocks originated from depleted mantle (materials that differentiated progressively to the granite (Oyinloye, 2011). Progressive differentiations of both primitive and depleted mantle basalt to form granite have been reported in the Kushaka basement rocks (Oluyede, 2020).

Comparison of the geology and chemical composition of the basement rocks of Birnin Gwari schist belt with those from adjourning Kushaka schist belt to the east, Wonaka schist belt to the northeast, Igarra schist belt and Ife-Ilesha schist belt in the south is similar with minor deviations locally (Table 5). Birnin Gwari basement rocks consists mainly banded and granitic gneiss, amphibolite, staurolitebiotite schist and syn-collision granite. Field investigations of Birnin Gwari schist belt have revealed lack of extrusive basalt except for volcanic clast in the biotite-staurolite quartz schist; however basalt from nearby Kushaka schist belt bear similarity with amphibolites in Wonaka and Ife-Ilesha schist belts in terms of elemental compositions except for the high $\mathrm{Na}_{2} \mathrm{O}$ content in the Wonaka schist belt. Additionally, the Birnin Gwari banded iron formation (BIF) earlier reported (Mücke, 2005) is geologically located in the Kushaka schist belt at the boundary close to Tsofon Birnin Gwari (Fig. 1), this rules out occurrence of BIF in Birnin Gwari schist belt. Amphibolite are characterized by brittle deformation, and similar to basalt in Kushaka schist belt and amphibolite in Wonaka and Ife-Ilesha schist belts, and agrees with derivation of the magmas from upper mantle melting as seen from data from basalt in Kushaka schist belt which revealed magma of back arc type (Oluyede and Klotzli, 2020a). Banded and granitic gneiss in Birnin Gwari also revealed igneous and metasedimentary sources as in the other schist belts. The metasediments show differences in the nature of protolith and environment of deposition, the Birnin Gwari metasediments have been interpreted as a simple immature shale-greywacke sedimentary protolith derived from granodioritic and granite-quartz monzonite provenance (Grant, 1978; Ajibade, et al., 2008; Oluyede et al., 2021c), while Kushaka metasediments is a matured arkosic and shale-greywacke protolith derived from quartzose sedimentary and granite-quartz monzonite provenance in a reducing environment (Oluyede et al., 2021c), the Igarra quartz-mica schist and quartzite in Idoani area is a meta-arkose, derived from a granitic-quartz-monzonitic source (Adegbuyi et al., 2017). Wonaka schist belt consists mainly of mudstones and marls; a product of three different facies of one sedimentary basin and westward progressive reduction of coarse grained clastic materials from the Kazaure belt, through the Karau-karau to the Wonaka belt; while the BIF in Wonka are interbedded with schist and are therefore syngenetic (Usman and Ibrahim 2017). The Birnin Gwari metasediments (biotite-staurolite quartz schist) is of peraluminous and calcalkaline character and have been interpreted as simple, immature, monocyclic sedimentary cover in-folded into basement complex during Pan-African event. The syn-collisional granite and quartzolite intruded both the banded and granitic gneiss and the staurolite-biotite quartz schist and have calc-alkaline and high-K calc-alkaline affinities, and calc-alkalic to alkali-calcic, peraluminous and ferroan and magnesian geochemistry and of diverse trend such as "high and low Ba-Sr"; "normal", "anomalous" "strongly differentiated" and "granodiorite and quartz diorite" granite (Oluyede and Klötzli, 2020a). The field and geochemical characteristics of the granite shows that they are similar to other granites in schist belts in other parts of Nigeria.

Table 3: A) Trace Elements (Ppm) Abundance in the Basement Rocks of the Northern Part of Birnin Gwari Schist Belt

\begin{tabular}{|c|c|c|c|c|c|c|c|c|c|c|}
\hline $\begin{array}{l}\text { Sample } \\
(\%)\end{array}$ & $\begin{array}{l}\text { BD1 } \\
\text { Diorite }\end{array}$ & $\begin{array}{l}\text { BTN2 } \\
\text { Tonalite }\end{array}$ & \multicolumn{3}{|c|}{ Granodiorite Paleosome } & \multicolumn{2}{|c|}{ Granite Leucosome } & \multicolumn{3}{|c|}{ Granite Gneiss } \\
\hline As & 0.8 & 2.4 & 0.2 & 2.4 & 2.8 & 2.2 & 4.6 & 2.5 & 2.9 & 3.8 \\
\hline $\mathrm{Ba}$ & 1723.3 & 1616.4 & 1247.3 & 764.7 & 217.5 & 104.5 & 519.8 & 1107.8 & 1445.5 & 33.3 \\
\hline $\mathrm{Ce}$ & 110 & 89.3 & 73.4 & 145.9 & 63.1 & 44.4 & 95.3 & 69.9 & 75.9 & 13.2 \\
\hline $\mathrm{Co}$ & 51.4 & 66.4 & 41.9 & 54.6 & 40.9 & 56.7 & 67.2 & 48.7 & 67.7 & 2.4 \\
\hline $\mathrm{Cr}$ & 132.3 & 50.3 & 43.6 & 38.7 & 89.2 & 7.8 & 14.4 & 7.4 & 3.7 & 10.6 \\
\hline $\mathrm{Cu}$ & 19.2 & 15.8 & 17.6 & 27.3 & 27.7 & 6.4 & 11 & 5.1 & 13.7 & 209.9 \\
\hline $\mathrm{Ga}$ & 18.4 & 20.4 & 19.1 & 19.5 & 17.5 & 13.7 & 17.4 & 14.3 & 11.4 & 3.3 \\
\hline Mo & 0.1 & 0.1 & $<1$ & 2.2 & 0.3 & 0.1 & 0.3 & 0.1 & 0.3 & $<1$ \\
\hline $\mathrm{Nb}$ & 17.4 & 8.7 & 15.1 & 26.3 & 10.4 & 7.3 & 18.3 & 7.8 & 10.3 & $<1$ \\
\hline $\mathrm{Nd}$ & 50.4 & 25.7 & 32 & 103.6 & 31.9 & 19.4 & 43.7 & 31.1 & 23.8 & 10.5 \\
\hline $\mathrm{Ni}$ & 59.3 & 15.9 & 6.7 & 14.3 & 29 & 2 & 5 & 0.9 & 1.2 & 1.8 \\
\hline $\mathrm{Pb}$ & 44.6 & 33.5 & 29.4 & 18.3 & 25.3 & 33.9 & 17.6 & 41 & 41.1 & 35.3 \\
\hline $\mathrm{Rb}$ & 198.4 & 89 & 146.8 & 151.4 & 63.7 & 430.1 & 132.8 & 102.6 & 140.9 & 13.6 \\
\hline $\mathrm{Sc}$ & 11.6 & 7.8 & 5.5 & 17.7 & 14.6 & 4.7 & 6.6 & 7.4 & 1 & $<1$ \\
\hline $\mathrm{Sn}$ & 8.4 & 7.8 & 8.2 & 8.1 & 3.8 & 10 & 7.9 & 5.9 & 8.2 & 38.6 \\
\hline $\mathrm{Ta}$ & $<1$ & $<1$ & $<1$ & $<1$ & $<1$ & $<1$ & 0.1 & $<1$ & $<1$ & $<1$ \\
\hline Th & 20.6 & 10.4 & 14.1 & 15.6 & 6.6 & 19.9 & 16.6 & 14.8 & 21.7 & $<1$ \\
\hline $\mathrm{U}$ & 8.7 & 5.5 & 4.9 & 3.2 & 2.3 & 14.2 & 2.5 & 3.7 & 5 & 0.9 \\
\hline V & 160.8 & 86.1 & 118.8 & 113.2 & 114.2 & 6.7 & 37.5 & 20.7 & 10.1 & 2.6 \\
\hline W & 177.7 & 292.6 & 156.5 & 246.6 & 172.5 & 394.8 & 361 & 254.8 & 367.4 & $<1$ \\
\hline $\mathrm{Y}$ & 27.5 & 14.9 & 25.9 & 93.1 & 45.3 & 41.9 & 51.2 & 31.6 & 21.5 & 3.6 \\
\hline $\mathrm{Zn}$ & 87 & 76.9 & 87.2 & 88.3 & 65.8 & 18.8 & 36.9 & 54 & 29.6 & 43.3 \\
\hline $\mathrm{Zr}$ & 204.6 & 169.4 & 221.6 & 318.4 & 160.9 & 57.3 & 227.5 & 166.4 & 175.4 & 28.2 \\
\hline
\end{tabular}


Table 3: B) Trace Elements (Ppm) Abundance in the Basement Rocks of the Northern Part of Birnin Gwari Schist Belt

\begin{tabular}{|c|c|c|c|c|c|c|c|c|c|}
\hline $\begin{array}{l}\text { Sample } \\
(\%)\end{array}$ & $\begin{array}{l}\text { BGN11 } \\
\text { Granite } \\
\text { Greiss }\end{array}$ & $\begin{array}{l}\text { BSc12 } \\
\text { Schist }\end{array}$ & BSc13 & $\begin{array}{l}\text { BG14 } \\
\text { Granite }\end{array}$ & BG15 & BG16 & BG17 & BG18 & $\begin{array}{l}\text { BQZL19 } \\
\text { Quartzolite }\end{array}$ \\
\hline As & $<1$ & $<1$ & $<1$ & 0.7 & 2.8 & 4.5 & 4.3 & 2.5 & 2.5 \\
\hline $\mathrm{Ce}$ & 22.3 & $<1$ & 6.2 & 127.6 & 27.6 & 12 & 0 & 92.7 & 10.6 \\
\hline Co & 3.5 & 0.7 & 0.3 & 44.4 & 49.9 & 60.5 & 47.4 & 102 & 55.8 \\
\hline $\mathrm{Cr}$ & 12.4 & 23.7 & 7.9 & 28.5 & 8.4 & 6.9 & 5.8 & 3.3 & 6.8 \\
\hline $\mathrm{Cu}$ & 218.5 & 210.8 & 210.6 & 14.8 & 5.4 & 8.7 & 5.6 & 4.8 & 3.3 \\
\hline $\mathrm{Ga}$ & 3.8 & 3.3 & 3.8 & 21.6 & 20.7 & 20.6 & 16.9 & 12.7 & 2 \\
\hline $\mathrm{La}$ & 26.2 & 9.1 & 16.4 & 77.5 & 13.7 & 1.9 & 0.5 & 157.2 & $<1$ \\
\hline Mo & $<1$ & $<1$ & $<1$ & 0 & $<1$ & 0.3 & 0 & 0.5 & $<1$ \\
\hline $\mathrm{Nb}$ & $<1$ & $<1$ & $<1$ & 16.6 & 10.6 & 30.5 & 17.7 & 9.2 & 6.6 \\
\hline $\mathrm{Nd}$ & 5.5 & $<1$ & 18.7 & 40.8 & 11.6 & 6 & 0.8 & 88.7 & 6.5 \\
\hline $\mathrm{Ni}$ & 4 & 2.1 & 1.8 & 8.3 & 0.9 & 1.5 & 0.9 & 1.4 & $<1$ \\
\hline $\mathrm{Pb}$ & 25.6 & 27.5 & 31.1 & 33.4 & 55.9 & 13.2 & 15.7 & 24.1 & 0.6 \\
\hline $\mathrm{Rb}$ & 12 & 14.4 & 13.5 & 215.5 & 180.1 & 387.5 & 363 & 156.1 & 6.5 \\
\hline $\mathrm{Sc}$ & $<1$ & $<1$ & 2.6 & 5.1 & 2.8 & 1.7 & $<1$ & 3.7 & 1.8 \\
\hline $\mathrm{Sr}$ & 290.8 & 557.6 & 134 & 285.3 & 133.1 & 38.5 & 26.3 & 46.1 & 8.2 \\
\hline $\mathrm{Ta}$ & $<1$ & $<1$ & $<1$ & 1.5 & 1 & 8.6 & 9.3 & $<1$ & $<1$ \\
\hline $\mathrm{Th}$ & $<1$ & $<1$ & $<1$ & 17.1 & 8.6 & 1 & 0.4 & 20.6 & 1.2 \\
\hline $\mathrm{U}$ & 2.7 & 6.4 & 1.1 & 3.4 & 5.9 & 9.5 & 15.7 & 6.5 & 0.1 \\
\hline V & 4 & 0.4 & $<1$ & 38.8 & 6.4 & 1.1 & $<1$ & 3.8 & 6.2 \\
\hline W & 2.3 & $<1$ & $<1$ & 252.9 & 293.8 & 337.3 & 349 & 570.4 & 341.8 \\
\hline Y & 2.9 & 2.9 & 3.6 & 27.4 & 9.4 & 6.1 & 4.5 & 60.5 & 13.9 \\
\hline $\mathrm{Zn}$ & 685.6 & 32.7 & 41.9 & 45.9 & 16.1 & 38.6 & 21.8 & 21.4 & 0.5 \\
\hline $\mathrm{Zr}$ & 20 & 35.3 & 28.3 & 150.6 & 64 & 30 & 22.4 & 144.1 & 135.3 \\
\hline
\end{tabular}

Table 4: REE Data (Ppm) on the Basement Rocks in the Birnin Gwari Schist Belt

\begin{tabular}{|c|c|c|c|c|c|c|c|c|}
\hline Sample & BD1 & BTN2 & BGD4 & BG7 & BGn11 & BSc12 & BG14 & BG16 \\
\hline $\mathrm{La}$ & 45.8 & 26.3 & 80.8 & 39.8 & 3.0 & 28.3 & 61.6 & 2.9 \\
\hline $\mathrm{Ce}$ & 91.05 & 56.72 & 123.11 & 82.16 & 6.79 & 56.89 & 111.15 & 5.87 \\
\hline $\operatorname{Pr}$ & 11.06 & 5.26 & 21.01 & 10.51 & 0.98 & 7.58 & 12.17 & 0.79 \\
\hline $\mathrm{Nd}$ & 39.7 & 16.8 & 81.4 & 38.7 & 4.1 & 29.1 & 38.4 & 2.8 \\
\hline $\mathrm{Sm}$ & 6.22 & 2.04 & 18.62 & 8.11 & 1.03 & 5.51 & 5.83 & 0.78 \\
\hline $\mathrm{Eu}$ & 1.12 & 0.42 & 2.86 & 0.96 & 0.24 & 1.16 & 0.64 & 0.16 \\
\hline $\mathrm{Gd}$ & 4.06 & 1.53 & 20.20 & 7.80 & 1.20 & 4.96 & 4.49 & 0.8 \\
\hline $\mathrm{Tb}$ & 0.39 & 0.15 & 3.02 & 1.16 & 0.20 & 0.62 & 0.54 & 0.14 \\
\hline Dy & 1.56 & 0.70 & 16.90 & 6.56 & 1.23 & 3 & 2.79 & 0.82 \\
\hline Ho & 0.24 & 0.12 & 2.83 & 1.13 & 0.20 & 0.45 & 0.49 & 0.13 \\
\hline $\mathrm{Er}$ & 0.57 & 0.33 & 6.37 & 2.64 & 0.44 & 0.98 & 1.25 & 0.33 \\
\hline $\mathrm{Tm}$ & 0.07 & 0.05 & 0.76 & 0.32 & 0.05 & 0.12 & 0.17 & 0.05 \\
\hline $\mathrm{Yb}$ & 0.40 & 0.27 & 3.97 & 1.66 & 1.93 & 0.61 & 0.92 & 0.29 \\
\hline $\mathrm{Lu}$ & 0.06 & 0.04 & 0.55 & 0.23 & 0.03 & 0.08 & 0.12 & 0.04 \\
\hline$\sum \mathrm{REE}$ & $202 . .3$ & 110.73 & 382.40 & 201.74 & 21.42 & 139.36 & 240.56 & 15.90 \\
\hline$(\mathrm{La} / \mathrm{Yb})_{\mathrm{N}}$ & 77.20 & 65.67 & 13.72 & 16.16 & 1.05 & 31.28 & 45.14 & 6.74 \\
\hline$(\mathrm{Ce} / \mathrm{Sm})_{\mathrm{N}}$ & 3.53 & 6.71 & 1.60 & 2.44 & 1.59 & 2.49 & 4.60 & 1.82 \\
\hline$(\mathrm{Eu} / \mathrm{Yb})_{\mathrm{N}}$ & 7.96 & 4.42 & 2.05 & 1.64 & 0.35 & 5.41 & 1.98 & 1.57 \\
\hline $\mathrm{Eu} / \mathrm{Eu}^{*}$ & 0.68 & 0.73 & 0.45 & 0.37 & 0.66 & 0.68 & 0.38 & 0.62 \\
\hline
\end{tabular}

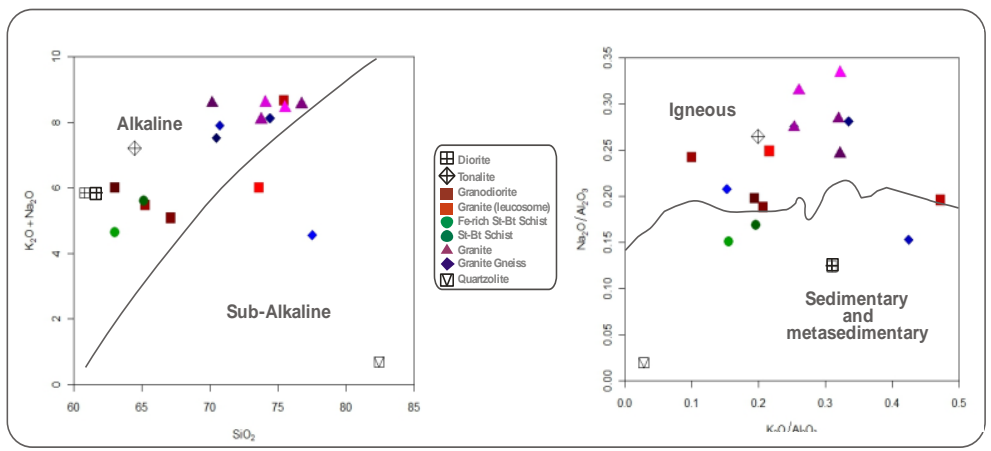

Fig. 4: $\mathrm{Na}_{2} \mathrm{O} / \mathrm{Al}_{2} \mathrm{O}_{3}$ Versus $\mathrm{K}_{2} \mathrm{O} / \mathrm{Al}_{2} \mathrm{O}_{3}$ Discrimination Diagram (After Irvine and Baragar, 1971) and $\mathrm{Na}_{2} \mathrm{O}+\mathrm{K}_{2} \mathrm{O}$ Against Sio 2 Plot $(\mathrm{After}$ Garrels and Mackenzie, 1971) of Birnin Gwari Basement Complex Rocks. 


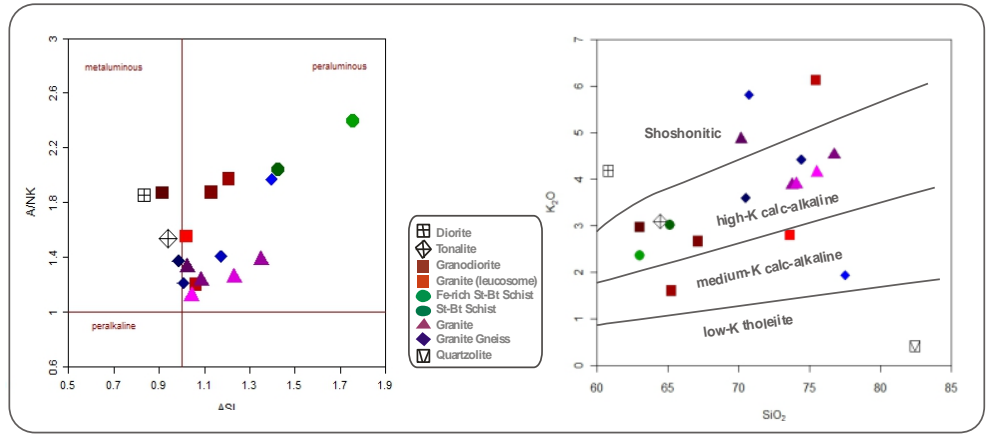

Fig. 5: ASI Versus A/NK $=\mathrm{Al}_{2} \mathrm{O}_{3} /\left(\mathrm{Na}_{2} \mathrm{O}+\mathrm{K}_{2} \mathrm{O}\right.$ Mol \%) Discrimination Diagram (After Frost Et Al., 2001) and $\mathrm{K}_{2} \mathrm{O}$ Versus Sio Plot $_{2}$ (After Rickwood, 1989) of Birnin Gwari Basement Complex Rocks.

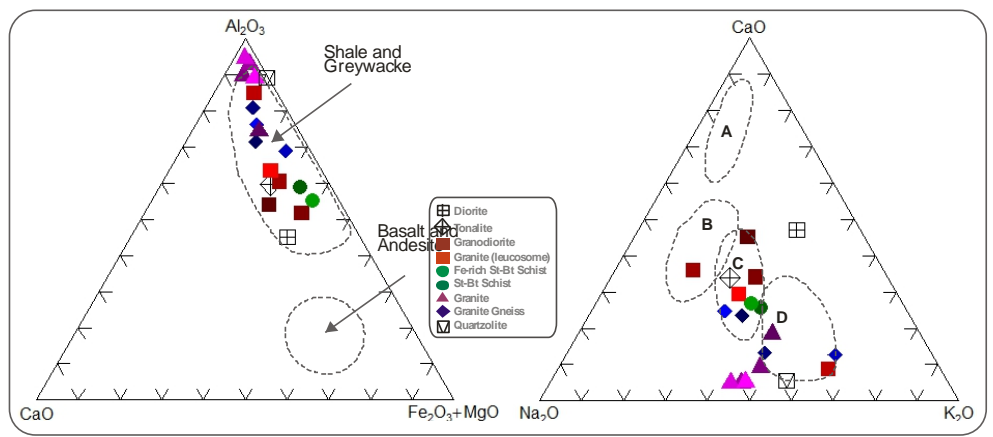

Fig. 6: ACF Diagram After (Miyashiro, 1978) and Cao- $\mathrm{Na}_{2} \mathrm{O}-\mathrm{K}_{2} \mathrm{O}$ Diagram After (Condie, 1967) of Birnin Gwari Basement Complex Rocks.
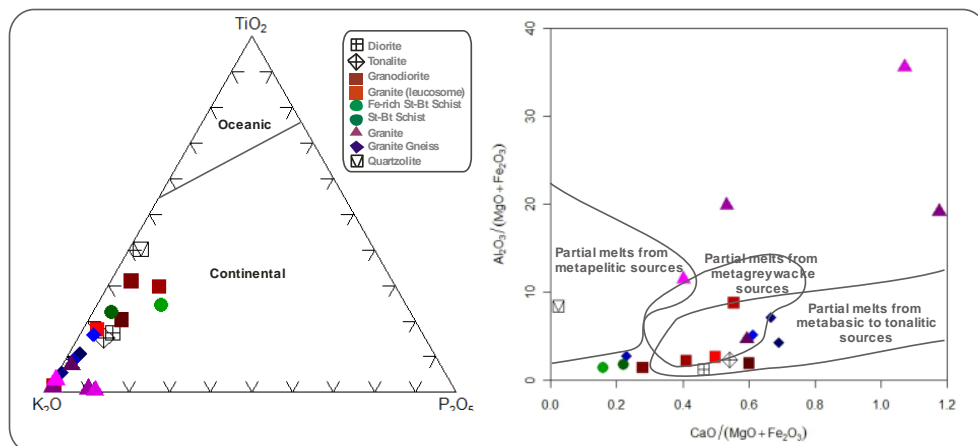

Fig. 7: $\mathrm{Tio}_{2}-\mathrm{K}_{2} \mathrm{O}-\mathrm{P}_{2} \mathrm{O}_{5}$ Plot (After Pearce Et Al., 1975) and Plots of Molar $\mathrm{Al}_{2} \mathrm{O}_{3} /\left(\mathrm{Mgo}+\mathrm{Fe}_{2} \mathrm{O}_{3}\right)-\mathrm{Cao} /\left(\mathrm{Mgo}+\mathrm{Fe}_{2} \mathrm{O}_{3}\right)$ Diagram (After Altherr Et Al., 2000) with Composition Fields of Partial Melts Derived from Experimental Dehydration-Melting of Various Source Rocks (Wolf and Wyllie, 1994; Gardien Et Al., 1995; Partino Douce and Beard, 1995; 1996; Singh and Johanneses, 1996) of Birnin Gwari Basement Complex Rocks.

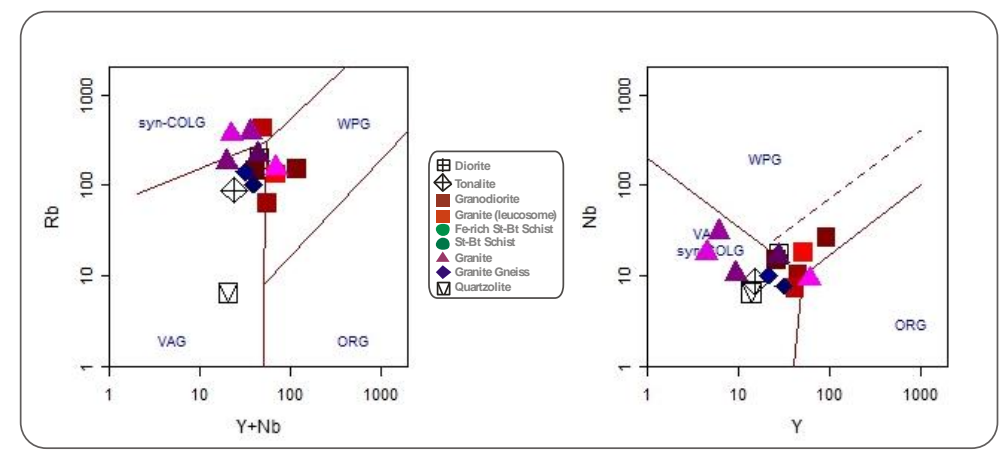

Fig. 8: Plots of $(\mathrm{Y}+\mathrm{Nb})$ vs $\mathrm{Rb}(\mathrm{In}$ Ppm) Geotectonic Discrimination Diagram (After Pearce Et Al., 1984) of Birnin Gwari Basement Complex Rocks (ORG=Ocean Ridge Granites, Syn-COLG=Syn-Collisional Granites, AG=Volcanic Arc Granites, WPG=Within Plate Granites). 


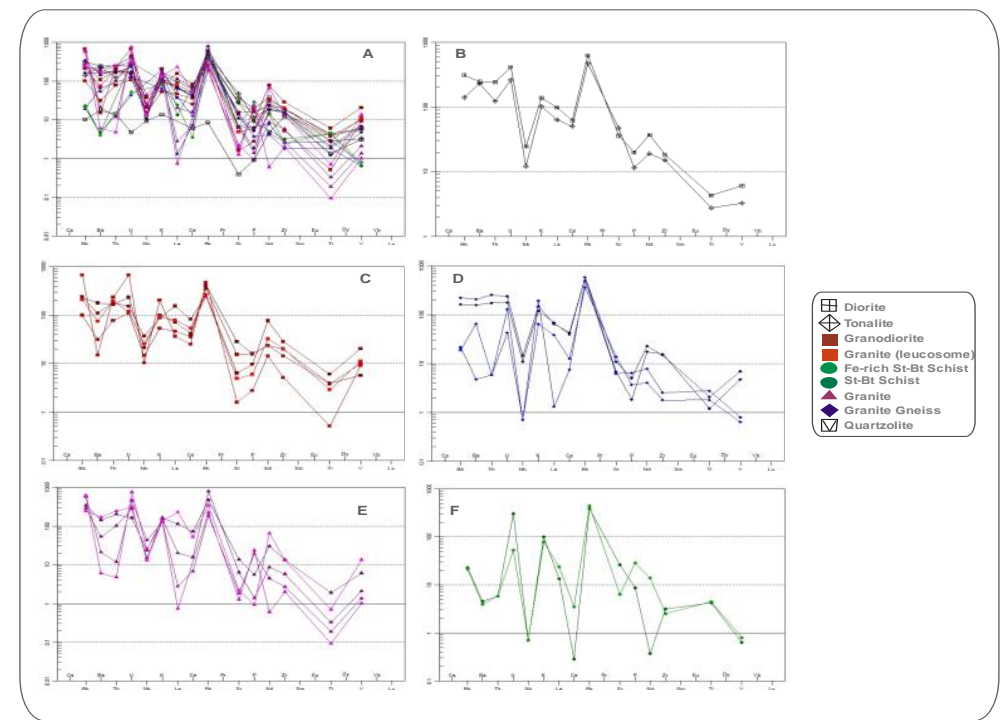

Fig. 9: Mantle-Normalized Multi-Element Diagram of (A) Different Rock Types; (B) Diorite and Tonalite; (C) Granodiorite and Granite Leucosome; (D) Granite Gneiss; (E) Granite; (F) Staurolite-Biotite Quartz Schist (After Sun and Mcdonough, 1989) in the Birnin Gwari Basement Rocks.

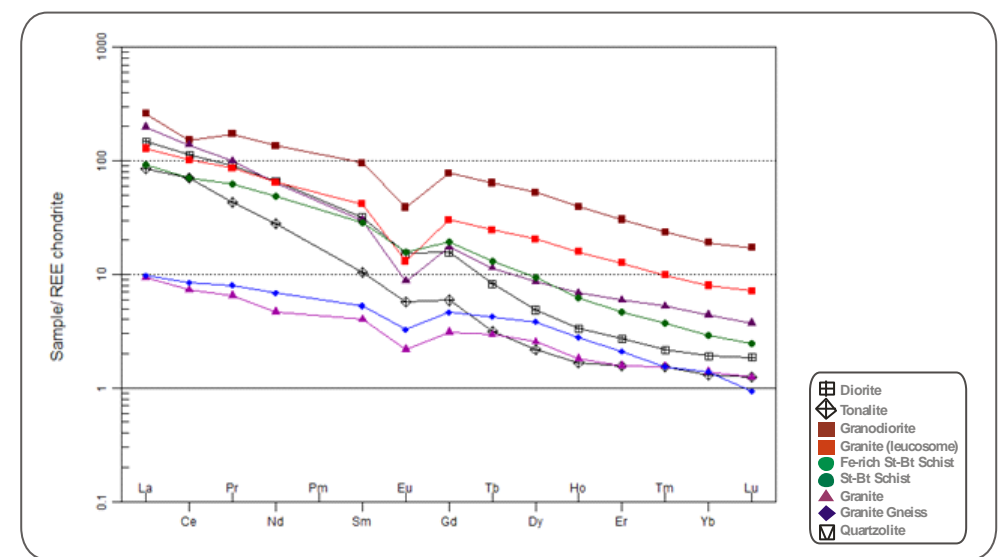

Fig. 10: Chondrite-Normalized Pattern (After Boynton, 1984) for the Birnin Gwari Basement Rocks.

Table 5: Comparison of Analytical Results of Rocks the Birnin Gwari Schist Belt with Other Schist Belts in Nigeria

\begin{tabular}{|c|c|c|c|c|c|c|c|c|c|c|c|c|c|c|c|c|c|c|}
\hline \multirow{2}{*}{$\begin{array}{l}\text { Samp } \\
\text { le } \\
(\%)\end{array}$} & \multicolumn{3}{|c|}{$\begin{array}{l}\text { (1) Rocks of Birnin } \\
\text { Gwari Schist Belt } \\
\text { (This Study) }\end{array}$} & \multicolumn{5}{|c|}{ (2) Rocks of Kushaka Schist Belt } & \multicolumn{4}{|c|}{$\begin{array}{l}\text { (3) Rocks of Wonaka Schist } \\
\text { Belt }\end{array}$} & \multicolumn{3}{|c|}{$\begin{array}{l}\text { (4) Rocks of Igarra } \\
\text { Schist Belt (Idoani) }\end{array}$} & \multicolumn{3}{|c|}{$\begin{array}{l}\text { (5) Rocks of IIfe- } \\
\text { Ilesha Schist Belt }\end{array}$} \\
\hline & $\begin{array}{l}\mathrm{BG} \\
\mathrm{N} \\
\mathrm{N}=1 \\
1\end{array}$ & $\begin{array}{l}\text { SBS } \\
\mathrm{N}=2\end{array}$ & $\begin{array}{l}\text { GR } \\
N \\
N=6\end{array}$ & $\begin{array}{l}\mathrm{BG} \\
\mathrm{N} \\
\mathrm{N}=1 \\
3\end{array}$ & $\begin{array}{l}\mathrm{SBM} \\
\mathrm{S} \\
\mathrm{N}=3\end{array}$ & $\begin{array}{l}\text { GR } \\
N \\
N=7\end{array}$ & $\begin{array}{l}\mathrm{BSL} \\
\mathrm{T} \\
\mathrm{N}=2\end{array}$ & $\begin{array}{l}\mathrm{BIF} \\
\mathrm{N}=1\end{array}$ & $\begin{array}{l}\mathrm{BG} \\
\mathrm{N} \\
\mathrm{N}=3\end{array}$ & $\begin{array}{l}\text { GR } \\
N \\
N=4\end{array}$ & $\begin{array}{l}A M \\
P \\
N=1\end{array}$ & $\begin{array}{l}\mathrm{BIF} \\
\mathrm{N}=4\end{array}$ & $\begin{array}{l}\mathrm{BG} \\
\mathrm{N} \\
\mathrm{N}=6\end{array}$ & & $\begin{array}{l}\text { GRN } \\
\mathrm{N}=8\end{array}$ & $\begin{array}{l}\mathrm{BGN} \\
\mathrm{N}=9\end{array}$ & $\begin{array}{l}\mathrm{BM} \\
\mathrm{S} \\
\mathrm{N}=3\end{array}$ & $\begin{array}{l}\mathrm{AM} \\
\mathrm{P} \\
\mathrm{N}=7\end{array}$ \\
\hline $\mathrm{SiO} 2$ & $\begin{array}{l}70.4 \\
9\end{array}$ & $\begin{array}{l}65.1 \\
3\end{array}$ & $\begin{array}{l}70.1 \\
5\end{array}$ & $\begin{array}{l}67.1 \\
1\end{array}$ & 64.2 & $\begin{array}{l}71.1 \\
2\end{array}$ & $\begin{array}{l}49.5 \\
6\end{array}$ & $\begin{array}{l}50.9 \\
8\end{array}$ & $\begin{array}{l}78.1 \\
2\end{array}$ & $\begin{array}{l}72.8 \\
6\end{array}$ & $\begin{array}{l}71.2 \\
4\end{array}$ & $\begin{array}{l}50.0 \\
9\end{array}$ & $\begin{array}{l}65.3 \\
1\end{array}$ & 69.68 & 68.01 & 73.21 & $\begin{array}{l}65.4 \\
2\end{array}$ & $\begin{array}{l}48.2 \\
2\end{array}$ \\
\hline $\mathrm{TiO} 2$ & 0.45 & 0.92 & 0.41 & 1.3 & 0.9 & 0.18 & 0.7 & 0.34 & 0.63 & 0.43 & 0.51 & 0.76 & 0.79 & 0.21 & 0.42 & 0.33 & 0.31 & 1.77 \\
\hline $\begin{array}{l}\mathrm{A} 12 \mathrm{O} \\
3\end{array}$ & $\begin{array}{l}14.2 \\
1\end{array}$ & 15.4 & $\begin{array}{l}15.1 \\
2\end{array}$ & $\begin{array}{l}12.8 \\
7\end{array}$ & $\begin{array}{l}19.7 \\
2\end{array}$ & $\begin{array}{l}15.0 \\
3\end{array}$ & $\begin{array}{l}14.7 \\
4\end{array}$ & $\begin{array}{l}10.4 \\
7\end{array}$ & $\begin{array}{l}12.3 \\
7\end{array}$ & $\begin{array}{l}13.9 \\
8\end{array}$ & $\begin{array}{l}13.4 \\
6\end{array}$ & 4.11 & $\begin{array}{l}16.2 \\
1\end{array}$ & 13.56 & 14.32 & 13.83 & $\begin{array}{l}13.8 \\
1\end{array}$ & $\begin{array}{l}13.7 \\
6\end{array}$ \\
\hline $\begin{array}{l}\mathrm{Fe} 2 \mathrm{O} \\
3\end{array}$ & 2.55 & 6.62 & 2.41 & 7.69 & 4.58 & 1.27 & $\begin{array}{l}10.1 \\
4\end{array}$ & $\begin{array}{l}29.2 \\
2\end{array}$ & 1.38 & 2.48 & 3.94 & $\begin{array}{l}39.0 \\
0\end{array}$ & 3.21 & 7.72 & 2.84 & 1.64 & 6.41 & $\begin{array}{l}17.8 \\
8\end{array}$ \\
\hline $\mathrm{MnO}$ & 0.09 & 0.11 & 0.04 & 0.17 & 0.05 & 003 & 0.16 & 5.19 & 0.03 & & 006 & 4.53 & 0.10 & & 0.05 & 0.02 & & 0.30 \\
\hline $\mathrm{MgO}$ & 0.79 & 2.17 & 0.86 & 1.71 & 0.93 & 0.45 & 8.96 & 1.82 & 1.90 & 1.04 & 8.00 & 0.64 & 1.24 & 0.16 & 2.31 & 0.51 & 2.64 & 6.85 \\
\hline $\mathrm{CaO}$ & 2.31 & 1.93 & 1.94 & 2.62 & 0.32 & 1.57 & $\begin{array}{l}12.6 \\
5\end{array}$ & 1.02 & 0.79 & 2.04 & 2.83 & 0.52 & 2.35 & 1.01 & 1.76 & 0.95 & 0.01 & 7.76 \\
\hline $\mathrm{Na} 2 \mathrm{O}$ & 3.92 & 2.6 & 3.72 & 2.42 & & & 1.4 & & & & & & & & & & & \\
\hline $\mathrm{K} 2 \mathrm{O}$ & 3.6 & 3.01 & 4.86 & 2.66 & 3.87 & 4.16 & 0.19 & 0.04 & 4.35 & 5.08 & 6.34 & 0.03 & 3.30 & 2.30 & 3.21 & 6.32 & 2.1 & 0.11 \\
\hline $\mathrm{P} 2 \mathrm{O} 5$ & 0.11 & 0.19 & 0.12 & 0.21 & 0.05 & 0.06 & 0.05 & 0.08 & 0.12 & 0.12 & 0.17 & 0.09 & 0.33 & & 2.54 & 0.03 & 0.20 & 0.04 \\
\hline LOI & 0.59 & 1.25 & 0.35 & 0.48 & 3.78 & 0.2 & 0.34 & 0.18 & & & & & 3.64 & 2.52 & 2.84 & 3.09 & 1.3 & 0.70 \\
\hline Total & $\begin{array}{l}99.1 \\
1\end{array}$ & $\begin{array}{l}99.3 \\
3\end{array}$ & $\begin{array}{l}99.9 \\
8\end{array}$ & $\begin{array}{l}99.2 \\
4\end{array}$ & $\begin{array}{l}99.5 \\
9\end{array}$ & $\begin{array}{l}98.9 \\
3\end{array}$ & $\begin{array}{l}100 . \\
1\end{array}$ & $\begin{array}{l}99.4 \\
9\end{array}$ & $\begin{array}{l}99.8 \\
1\end{array}$ & $\begin{array}{l}99.1 \\
7\end{array}$ & $\begin{array}{l}98.6 \\
0\end{array}$ & $\begin{array}{l}99.3 \\
7\end{array}$ & $\begin{array}{l}100 . \\
5\end{array}$ & $\begin{array}{l}100.2 \\
6\end{array}$ & $\begin{array}{l}100.1 \\
0\end{array}$ & $\begin{array}{l}101.5 \\
4\end{array}$ & $\begin{array}{l}99.8 \\
6\end{array}$ & $\begin{array}{l}99.7 \\
0\end{array}$ \\
\hline
\end{tabular}

BSLT=Basalt, AMP=Amphibolite, BGN=Granite Gneiss, GRA=Granite, SBMS=Staurolite-Biotite-Muscovite Schist, SBS=Staurolite-Biotite Schist, BMS=Biotite Mica Schist, QMS=Quartz Mica Schist, BMS=Biotite Mica Schist, BIF=Banded Iron Formation.

1) Birnin Gwari Schist Belt: This Study (BGN, SBS, GRN)

2) Kushaka Schist Belt: BGN, SBS, GR (Oluyede, 2020)

3) Wonaka Schist Belt: AMP, BGN, GN, BIF (Usman and Ibrahim, 2017)

4) Igarra Schist Belt (Idoani): BGN, QMS, GR (Adegbuyi et al., 2017)

5) Ife-Ilesha Schist Belt: BMS (Okunlola and Okoroafor, 2009); BGN (Oyinloye, 2004); AMP (Bolarinwa and Adepoju, 2017). 


\section{Conclusions}

The alkaline Basement Complex rocks of Birnin Gwari schist belt comprise banded and granitic gneiss; biotite-staurolite quartz schist and syn-tectonic granite and quartzolite. Banded gneisses are of hybrid sedimentary-igneous protoliths and their pelitic and mafic protoliths were derived essentially from a quartz-diorite, granodiorite and granite-quartz monzonite source. Pyroxene minerals in banded gneiss of dioritic and granodioritic compositions, lend credence to anatexis, where amphibolite facies metamorphism may have locally attained grannulite facies. The metasediments (biotite-staurolite quartz schist) are simple, immature, monocyclic sedimentary cover infolded into basement complex during Pan-African event. Quartzolite is syn-tectonic and of tholeiitic affinity while granites are syntectonic and shows diverse trend such as high and low Ba-Sr granite; "granodiorite and quartz diorite"; "normal", "anomalous" and "strongly differentiated" granite with LILE enrichment, with low to high fractionation and depleted $\mathrm{Nb}$ and Ti anomalies, typical of subduction related environment in volcanic arc and post collisional settings. Precursor of these rocks originated from a basalt of depleted mantle that differentiated progressively to the granite.

\section{Acknowledgement}

The author acknowledge Mr Adekunle Omokanye for his assistance as a guide during the field mapping exercise and is indebted to Prof. Urs Klötzli and the staff of Geochronology Laboratory for their assistance and efforts in carrying out the geochemical analysis for the whole rock major and trace elements. Dr Abdulrasak Garba, Director General, Nigeria Geological Survey Agency, Abuja assisted greatly in the REE analysis. Insights and contributions of Prof. Abba and Prof. Ajibade in the course of this work are greatly acknowledged. The efforts of Prof. Najime Tavershima, Head, Geology Department, Dr S. S. Magaji, Mr. A.K. Amuda and Mr Animashaun of the Department of Geology, Ahmadu Bello University Zaria are equally acknowledged. The help of Peter Nagl, University of Vienna, with the whole rock geochemical analysis is also acknowledged.

\section{References}

[1] Ajibade, A. C., Fitches, W. R. and Wright J. B. 1979. The Zungeru mylonites, Nigeria: recognition of a major tectonic unit. Revue De Geologie et Geographie Physique, 21, 359-363.

[2] Ajibade, A. C. (1980): Geotectonic evolution of Zungeru Region, Nigeria. Unpublished PhD Thesis, University of Wales Aberyswyth, 421.

[3] Ajibade A. C., Anyanwu, N. P. C., Okoro, A. U. and Nwajide, C. S. (2008). The Geology of Minna area. Nigeria Geological Survey Agency Bulletin No 43 .

[4] Adegbuyi, O.1., Ogunyele, A.C., Odindu, M., and Erinfolami, T. (2017). Geochemical Characteristics and Petrogenesis of Basement Rocks in Idoani Area, Ondo State, Southwestern Nigeria. International Journal of Advanced Geosciences, 5 (2), 102-108 https://doi.org/10.14419/ijag.v5i2.8377.

[5] Altherr, A. Holl, E. Hegner, C. Langer and Kreuzer, H. 2000. High potassium, calc-alkaline I-type plutonism in the European Variscides: northern Vosges (France) and northern Schwarzwald (Germany), Lithos 50, 51-73. https://doi.org/10.1016/S0024-4937(99)00052-3.

[6] Boynton W.V. 1984. Cosmochemistry of the rare earth elements; meteorite studies. In: Henderson P. (Ed.). Rare Earth element geochemistry. Amsterdam: Elsevier. 63-114. https://doi.org/10.1016/B978-0-444-42148-7.50008-3.

[7] Condie, K. C. (1967): Geochemistry of early Precambrian grey-wackes from Wyoming. Geochim.Comochim.Acta, Vol. 31, $2135-2149$. https://doi.org/10.1016/0016-7037(67)90057-9.

[8] Ferre, E. C., Caby, R., Peucat, J. J., Capdevila, I. R., and Monie, P., 1998. Pan-African post-collisional, ferro-potassic granite and quartz-monzonite plutons of Eastern Nigeria. Lithos, 45, 255 278. https://doi.org/10.1016/S0024-4937(98)00035-8.

[9] Frost, B. R., Barnes, C. G., Collins, W. J., Arculus, R. J., Ellis, D. J., \& Frost, C. D. (2001). A geochemical classification for granitic rocks. Journal of Petrology, 42, 2033-2048. https://doi.org/10.1093/petrology/42.11.2033.

[10] Garrels, R. M. \& Mackenzie, F. T. (1971). Evolution of sedimentary rocks. W.W. Norton and Company, Incorporated. New York, 394.

[11] Garba, I. 2003. The Nigerian gold deposits: geological settings, geochemical characteristics and origin. African Geosciences Review 10, (1-2), 109119.

[12] Gardien, V., Thompson, A. B., Grujic, D. and Ulmer, P. 1995. Experimental melting of biotite + plagioclase + quartz \pm muscovite assemblage and implications for crustal melting, Journal of Geophysical Research 100 (1995), 15581-15591. https://doi.org/10.1029/95JB00916.

[13] Grant, N. K. 1978. Structural distinction between metasedimentary cover and an underlying basement in the 600 m.y. old Pan-African domain of Northwestern Nigeria, West African. Geological Society America Bulletin 89, 50-58. https://doi.org/10.1130/00167606(1978)89<50:SDBAMC $>2.0 . \mathrm{CO} ; 2$.

[14] Irvine, T. N., and Baragar, W. R. A. 1971. A Guide to the Chemical Classification of Common Volcanic Rocks. Canadian Journal of Earth Sciences, 8, (5), 523-548. https://doi.org/10.1139/e71-055.

[15] Machado, A. Lima, E. F. Chemale, F. J. 2005. Geochemistry Constraints of Mesozoic-Cenozoic Calc-Alkaline Magmatism in the South Shetland Arc, Antarctica. Journal of South American Earth Sciences. Vol. 18, No. 3-4, 407-425. https://doi.org/10.1016/j.jsames.2004.11.011.

[16] Miyashiro A (1978). Nature of alkalic volcanic rock series. Contributions to Mineralogy and Petrology 66: 91-104. https://doi.org/10.1007/BF00376089.

[17] Mucke, 2005. The Nigerian manganese-rich iron-formations and their host rocks - from sedimentation to metamorphism. Journal of African Earth Sciences. 41, 407 - 436. https://doi.org/10.1016/j.jafrearsci.2005.07.003.

[18] Oluyede, K., Garba, I., Danbatta, U., Ogunleye, P. and Klötzli, U. (2021a). Field occurrence, petrography and structural characteristics of basement rocks of the northern part of Kushaka and Birnin Gwari schist belts, northwestern Nigeria. Journal of Natural Science Research. https://doi.org/10.7176/JNSR.

[19] Oluyede, K., Garba, I., Danbatta, U., Ogunleye, P. and Klötzli, U. (2021b). Geochemistry and petrogenesis of banded and granitic gneisses of the northern part of Kushaka schist belts northwestern Nigeria. Journal of Environmental and Earth Science. https://doi.org/10.7176/JEES.

[20] Oluyede, K., Garba, I., Danbatta, U., Ogunleye, P. and Klötzli, U. (2021c). Geochemistry and petrogenetic features of metasediments in central and northern part of Kushaka and Birnin Gwari schist belts NW Nigeria. https://doi.org/10.7176/JEES.

[21] Oluyede, K. and Klötzli, U. (2020a). Syn-collisional Pan-African granite in the northern part the Birnin Gwari Schist Belt, NW Nigeria International Journal of Advanced Geosciences Vol. 8 No. 2. pp 197-213. https://doi.org/10.14419/ijag.v8i2.31095.

[22] Oluyede, O. K. and Klötzli, U. (2020b). Syn-collisional and late orogenic Pan-African granite in the northern part the Kushaka Schist Belt, NW Nigeria. Journal of Open Geology (Paper ID: 1211425) https://doi.org/10.14419/ijag.v8i2.31095.

[23] Oluyede, O. K. (2020). Rocks of the northern part of Kushaka schist belts, Northwestern Nigeria: Provenance and Evolution. Open Journal of Geology (Paper ID 1211429).

[24] Oyinloye, A. O. (2011). Geology and Geotectonic Setting of the Basement Complex Rocks in South Western Nigeria: Implications on Provenance and Evolution, Earth and Environmental Sciences, Dr. Imran Ahmad Dar (Ed.), ISBN: 978-953-307-468-9, InTech, Available from: 
http://www.intechopen.com/books/earthand-environmental-sciences/geology-and-geotectonic-setting-of-the-basement-complex-rocks-insouthwestern-nigeria-implications.

[25] Pearce, J. A. Harris, N. B. W. and Tindle, A. G. W. 1984. Trace Element Discrimination Diagrams for the Tectonic İnterpretation of Granitic Rocks. Journal of Petrology, 25, (4), 956-983. https://doi.org/10.1093/petrology/25.4.956.

[26] Pearce, .M., Gorman , B. E. \& Birkett ,T. C. (1975): The Relationship between Major Element Chemistry and Tectonic Environment of basic and intermediate Volcanic Rocks. Earth Science Planetary Letters, 36, 121-132. https://doi.org/10.1016/0012-821X(77)90193-5.

[27] Partino Douce and Beard, 1995 A.E. Partino Douce and J.S. Beard, Dehydratation-melting of biotite gneiss and quartz amphibolite from 3 to 15 kbar, Journal of Petrology 36, 707-738. https://doi.org/10.1093/petrology/36.3.707.

[28] Partino Douce and Beard, 1996 A.E. Partino Douce and J.S. Beard, Effects of P, f (O2) and Mg/Fe ratio on dehydratation melting of model metagreywackes, Journal of Petrology 37, 999-1024. https://doi.org/10.1093/petrology/37.5.999.

[29] Rickwood, P. C. (1989): Boundary lines within petrologic diagrams which use oxides of major and minor elements. Lithos, $22,247-263$. https://doi.org/10.1016/0024-4937(89)90028-5. Soesoo, A. 2000. Fractional Crystallization ofmantle-derived melts as a mechanism for some I-type granite petrogenesis: an example from Lachlan Fold Belt, Australia. Journal of Geological Society, London 157, 135-149. https://doi.org/10.1016/0024-4937(89)90028-5.

[30] Singh, J. and Johanneses, W. 1996. Dehydration melting of tonalites: Part II. Composition of melts and solids, Contributions to Mineralogy and Petrology 125, 26-44. Sun S. S. and McDonough, W. F. (1989). Chemical and isotopic systematics of oceanic basalts: implications for mantle composition and processes. In: Saunders A.D., Norry M.J. (Eds.). Magmatism in the ocean basins. Geological Society of London, Special Publication, 42:313-345. https://doi.org/10.1144/GSL.SP.1989.042.01.19.

[31] Turner, D. C. 1983: Upper Proterozoic schist belts in the Nigerian sector of the Pan African Province of West Africa. Precambrian Research 21, 579. https://doi.org/10.1016/0301-9268(83)90005-0.

[32] Truswell, J. F. and Cope, R. N. 1963. The geology of parts of Niger and Zaria Provinces, Northern Nigeria. Bulletin Geological Survey Nigerian $29,38$.

[33] Usman, M. A. and Ibrahim, A. A. 2017. Petrography and Geochemistry of Rocks of Northern Part of Wonaka Schist Belt, Northwestern Nigeria. Nigerian Journal of Basic and Applied Science (December 2017), 25(2): 87-99. https://doi.org/10.4314/njbas.v25i2.10.

[34] Whalen J. B., Currie K. L. and Chappell B. W. 1987. A-type granites: Geochemical characteristics, discrimination and petrogenesis. Contributions Mineralogy and Petrology 95: 407-419. https://doi.org/10.1007/BF00402202.

[35] Wolf, M.B. and Wyllie, J.P. 1994. Dehydration-melting of amphibolite at 10 kbars: the effects of temperature and time, Contributions to Mineralogy and Petrology 115, 369-383. https://doi.org/10.1007/BF00320972. 